\title{
Less Teaching and The Effect on Psychomotor of Wood Building Practices in Product Education Techniques of Undana Building
}

\author{
Harijono \\ Building Engineering Education Department, \\ Teacher Training and Education Faculty, \\ University of Nusa Cendana \\ Kupang, Indonesia \\ harijono69@gmail.com
}

\begin{abstract}
This study aims to test the effectiveness of teaching methods and timing of feedback. The design used is experimental research. The results showed that there was an increase in learning. After students engaged in teaching and learning process using feedback method, the learning media teaching method gave back as a better teaching medium. In addition, there was an increase in students' attitudes toward wood practice lessons after the students following the learning process by using teaching reversal as a method of teaching in a lecture of building engineering education. Teaching method learning outcomes gave back to students in educational engineering development program as a result of better teaching.
\end{abstract}

Keywords-Less teaching, psychomotor

\section{INTRODUCTION}

Education should be able to produce personnel in accordance with the needs of the community. It is generally mentioned that educational programs at all levels should be planned based on a clear energy needs plan. Therefore, the concept of link and Match is more focused on one's readiness to meet the needs of the labor market in education. Preparation of a professional workforce may be undertaken by a bachelor of education. Thus, Bachelor degree program of building engineering education is expected to implement a relevant vocational education program with a target of reliable expertise in accordance with the needs of the industrial world in education. This is in line with the meaning of education constructivism as one of the philosophy which believes that the knowledge we have is the result of our own construction (formation). Knowledge is not a description of the real world or reality, but the result of a cognitive construct of reality through one's activities. The process of knowledge formation is continuous and every time there is a reorganization because there is a new understanding, and focusing on improving the quality of human resources.

To educate Technology and Vocational Education, Faculty of Teacher Training and Education Nusa Cendana University educational building engineering can produce graduates in accordance with the expected qualification. Therefore, the management of teaching and learning process needs to be managed properly and in accordance with the characteristics of technical education that is teaching and learning process emphasizing psychomotor domain.
Learning psychomotor skills in building engineering has different characteristics from learning cognitive aspect. Psychomotor skills include muscle skill and mind as well as muscle coordination. In the teaching of psychomotor skills, training is required. To facilitate the exercise, an example from the teacher is required. Thus, in teaching psychomotor skills, the method of demonstration is more important than the lecture method. There is a tendency that the combination of lecture demonstrations is better in woodwork and immediate repayment is better than immediate feedback. The problem that arises is whether the correct method of lecturedemonstration combination used when the students were given feedback immediately will give a low result or not?

This research is expected to find the teaching method and effective time to give feedback in teaching psychomotor skill / building technique, so that it can improve the learning result of psychomotor skill / building technique. This expectation is in line with the main objectives of technological and vocational education, namely to prepare ready-to-use workers, in addition to professional, business insights, and provide the possibility of continuing to a higher level education.

\section{METHOD}

The design of this study is pseudo factorial experiments because researchers want to know the effect of two independent variables at once and the determination of the subject in the group cannot be done randomly. This research is an educational research with applied research design (operational research) method of measurement using reverse method of wood practice with Paired samples T Test to test the average between two paired samples. This research was about the presence or absence of relationship or influence before and after treatment, then the two results of the measurement were analyzed to see the difference of further effectiveness of treatment, then the data collected in this study were analyzed through t-test between the results before the development of design or post-design research practice of wood.

\section{RESULT AND DISSCUSSION}

Psychomotor learning outcomes / woodworking skills involved in the teaching and learning process in using methods of reversing timber practices were considered as a 
good model. In addition there was an increase in student attitudes toward learning psychomotor feedback after students follow the learning process by using psychomotor learning model by giving feedback. From the results, the difference can be tested between the use of counters and not using feedback especially on wood practice learning in the Department of Technology and Vocational Education Building engineering education programs. The data can be input by employing computer-assisted as much as 20 students and can be arranged in the table as follows:

TABLE I. OUTPUT DISTRIBUTION OF FIELD RESEARCH DATA

\begin{tabular}{|c|c|c|}
\hline No & Before use reversal & After the use of feedback \\
\hline 1 & 76 & 85 \\
\hline 2 & 65 & 75 \\
\hline 3 & 72 & 84 \\
\hline 4 & 76 & 86 \\
\hline 5 & 65 & 75 \\
\hline 6 & 75 & 82 \\
\hline 7 & 78 & 85 \\
\hline 8 & 80 & 87 \\
\hline 9 & 75 & 82 \\
\hline 10 & 79 & 85 \\
\hline 11 & 76 & 85 \\
\hline 12 & 65 & 75 \\
\hline 13 & 72 & 84 \\
\hline 14 & 76 & 86 \\
\hline 15 & 65 & 75 \\
\hline 16 & 75 & 82 \\
\hline 17 & 78 & 85 \\
\hline 18 & 80 & 87 \\
\hline 19 & 75 & 82 \\
\hline 20 & 79 & 85 \\
\hline
\end{tabular}

The results of the analysis of Paired Samples statistics output

TABLE II. PAIRED SAMPLES Statistics

\begin{tabular}{|l|l|l|l|l|l|}
\hline \multicolumn{2}{|l|}{} & Mean & N & \multicolumn{1}{|c|}{$\begin{array}{c}\text { Std. } \\
\text { Deviation }\end{array}$} & $\begin{array}{c}\text { Std. Error } \\
\text { Mean }\end{array}$ \\
\hline Pair 1 & $\begin{array}{l}\text { Before using } \\
\text { learn back } \\
\text { learning } \\
\text { practice Study } \\
\text { Program of } \\
\text { Building } \\
\text { Engineering } \\
\text { Education }\end{array}$ & 20 & 5.15956 & 1.15371 \\
\hline $\begin{array}{l}\text { After using } \\
\text { learn back } \\
\text { learning } 82.6000 \\
\text { practice Study } \\
\text { Program of } \\
\text { Building } \\
\text { Engineering } \\
\text { Education }\end{array}$ & 20 & 4.18519 & 0.93584 \\
\hline
\end{tabular}

For data before reverse timber practice, the average value was 74.1000 , the number of test data was 20 , the standard deviation was 5.15956, and standard error mean was 1.15371. Meanwhile, for data after the return of wood practices, the average value was 82.6000 , the number of test data was 20, the standard deviation was 4.18519, and standard error mean was 0.93584 .

The results of the analysis of Paired samples Correlations output
TABLE III. PAIRED SAMPLES CORRELATIONS

\begin{tabular}{|l|l|l|l|c|}
\hline & & N & Correlation & Sig. \\
\hline Pair 1 & $\begin{array}{l}\text { Before using the lesson learned } \\
\text { study of wood \& After using the } \\
\text { learning back learning wood } \\
\text { Study Program of Building } \\
\text { Engineering Education }\end{array}$ & 0.938 & 0.000 \\
\hline
\end{tabular}

From the output, it was obtained the correlation value of 0.938 with significance 0.000 This means there was a relationship or a very strong influence between the value of the test before reverse timber practices and tests after reversing the practice of wood since the value was close to 1 .

The result of Paired Samples Test:

TABLE IV. PAIREd SAMPles Test

\begin{tabular}{|l|l|c|c|c|}
\hline \multicolumn{2}{|l|}{} & t & df & $\begin{array}{l}\text { Sig. (2- } \\
\text { tailed) }\end{array}$ \\
\hline Pair 1 & $\begin{array}{l}\text { Before using the lesson learned } \\
\text { study of wood \& After using the } \\
\text { learning back learning wood Study }\end{array}$ & $\begin{array}{l}\text { Program of Building Engineering } \\
\text { Education }\end{array}$ & 19.947 & 0.000 \\
\hline
\end{tabular}

The Paired samples T test was used to determine whether there was a difference in test scores between before reverse timber practices and after reversal of timber practices, the testing of learning on wood practices was conducted. Testing used a significance level of 0.05 and the following test steps are as follows:

\section{1) By formulating the hypothesis}

Ho: There is no difference in mean test scores between before learning using wood practice and after learning using wood practice.

Ha: There is an average difference between the preliminary test scores before learning using wood practices and after learning using wood practices

2) Determining $t$ arithmetic and significance, from the known output value of the count which was -19.947 and significance 0.000 .

3) Determining $t$ table: $\mathrm{T}$ table can be seen in the statistics table on the significance of $0.05: 2=0.025$ (2sided test) with degrees of freedom (df) $n-1$ or $20-1=19$. The results obtained for $\mathrm{t}$ table was 2.093 (see table $\mathrm{t}$ )

\section{4) Criteria testing:}

If - $\mathrm{t}$ table $<\mathrm{t}$ count $<\mathrm{t}$ table, then Ho is accepted.

If $-\mathrm{t}$ arithmetic $<-\mathrm{t}$ table or $\mathrm{t}$ arithmetic $>\mathrm{t}$ table or $\mathrm{t}$ count $>\mathrm{t}$ table, then Ho is rejected

Based on the significance:

If significance $>0,05$, then Ho is accepted

If significance $<0,05$, then Ho is rejected

5) Conclusions of the study because the value - $\mathrm{t}$ arithmetic $<-$ t table $(-19,947<-2,093)$ and the significance of the difference between the mean value of the test between before learning using learning back up wood practices and after learning using reverse wood practices. From the 
computer calculation (SPSS program), it can also be known the average value of the test after learning using the reverse practice of wood. It can be interpreted that the existence of this learning contributed in increasing the test value of learners in which will improve the psychomotor and their achievement.

Thus, it can be concluded that the use of psychomotor learning time of giving back to produce higher learning achievement than those who do not use learning using feedback.

Learning psychomotor skills building techniques has different characteristics with learning aspects of cognitive [5]. Psychomotor skills include muscle skills and mind as well as muscle coordination. In teaching psychomotor skills, practice is required. To expedite the exercise, teachers' example is required. Thus, demonstration method of psychomotor skills is better than lecture methods.

Therefore, the term learning outcome is identical with the acquisition of learning which refers to the students' mastery of the predetermined teaching objectives. It can be seen from the psychological dimension in which mainly referred to Gagne's opinion in Setjo [17], learning outcomes can be termed into dimensions 1) verbal information, 2) intellectual ability, 3) cognitive strategy, 4) attitude and 5) motor skills. The subjects were the students of the Faculty of Teacher Training and Education, especially in the building engineering education major. This course contains important or essential concepts of direction and insight, principles, objectives, scope, and approaches.

According to [5], there are three aspects of learning methods that are cognitive, affective and psychomotor which can be formed through the method of demonstration with different portions. With the right demonstration, it can create a good impression. This good impression prioritizes students' memory which can improve students' learning outcomes. [11] said that in teaching physical skills, the sense of sight is more important than the sense of hearing.

According to [15], the improvement of students' motor performance is dependent. The feedback can also monitor and organize the next activity. Being off to the correct performance can strengthen the next activity. Being off to the correct performance can strengthen learning and motivation to learn more. Similarly, feedback on the wrong performance can also be given so that students can improve their performance, in behavior and theory / practice of workshop technology and professional mechanical engineering.

Harijono (2012) stated that learning wood structure is a subject in the building engineering education study program in accordance with the syllabus. Therefore, Syllabus is the reference of learning containing the identity of the course. Wood Structure or lesson theme includes Learning Meter Wood Structure, Learning Activity, Competency Achievement Indicator, Assessment, Time Allocation and Learning Resources. Therefore, in the course, wood structure syllabus developed by educational unit based on standard contents and graduate competency standards. The syllabus is also as the preparation of educational unit level curriculum in the customized wood structure course that later on are prospective teachers or vocational schools. The implementation of learning wooden structure course at Technology and Vocational Education Faculty of Teacher Training and Education, the study program of building engineering education according to the instructional strategy in the development of syllabus of wood structure course in program study, building engineering education study program can be done by lecturers independently or grouped in accordance with the school, in this case a vocational high school [1].

\section{CONCLUSION}

The learning result of the teaching method of giving back to the students in the education engineering building program of Nusa Cendana University as teaching result was better. There was an improvement in students' attitude in the study program of building engineering education on psychomotor lessons with the teaching of reversal methods. After doing statistical test with anova one lane, it is believed that the use of teaching with reverse method to give lecture of wooden building practice can increase motivation, achievement of learning result especially related to psychomotor. In conclusion, teaching students in education of building technique of Nusa Cendana University required to teach feedback.

\section{ACKNOWLEDGMENT}

Acknowledgments are submitted to the Directorate of Research and Community Service of the Directorate General for Research and Development of the Ministry of Research, Technology and Higher Education in accordance with the Research Contract Number 142/UN15.19/LT/2018 dated February 1, 2018.

\section{REFERENCES}

[1] Abdul Majid, 2014, Strategi Pembelajaran, Penerbit PT Remaja Rosdakarya, Bandung

[2] Arends, RI, 2001, Classroom Instructional and Management. New York: Mc Graw-Hill Book Companies. Inc

[3] Bogdan \& Biklen, 2002, Qualitative Research for Education: An Introductionto Theory and Methaonds. Boston: Allyn and bacon Inc

[4] Colins, Angelo, 2002, Portopolio for Science Education: Issues in Purpose, Structure and Autenticity: Science Education 76 (4): 451463

[5] Dimyati, 2014, Belajar dan Pembelajaran, Penerbit Rineka Cipta,kerja sama Departemen Pendidikan dan Kebudayaan, Jakarta

[6] Gronlund, Norman E, (2000) Assesment of Student Achievement Sixth Edition. Allyn and Bacon, Boston

[7] Harijono, 2012, Bahan Ajar Struktur Kayu, Program Studi Pendidikan Teknik Bangunan. Jurusan PTK FKIP Universitas Nusa Cendana, Kupang

[8] Hartoyo, 2009, Penerapan Model Pembelajaran Kontekstual Berbasis Kompetensi untuk Meningkatkan Efektifitas Pembelajaran, Jurnal Ilmiah Penelitian Kependidikan, ISSN: 0125 - 092x XXXiX, Nomor I, Mei 2009, hal. $93-108$

[9] Hopkins, 2002, A Teacher's Guide to Classroom Research. Philadelpia: Open University

[10] Joice \& Weil, 2002, Models Of Teaching. Englewood Cliffs, NJ: Prentice Hall Inc

[11] Kasihani, 2014, Model - Model Pembelajaran, Kementerian Pendidikan Nasional, Universitas Negeri Malang, Panitia Sertifikasi Dosen (PSG), Rayon 15 Malang

[12] Kemmis MC dan Taggart R, 2000, The Action Research Planner, Victoria: Deakin UnVersity Prees

[13] Kemp J dan Toporoff, 2000, Guidelines for Potopolio Assesment in Teaching English kempa @ netvision, net il, diakses 25 Nopember 2017

[14] Leinhart, G, 2002, What Research on Learning In K.M. Cauley, F. Linder, J.H Mc Millan (eds), Annual Editions: Educational 
[17] Setjo, 2011, Meningkatkan Pemahaman Konsep Tentang Virus Dengan Penggunaan Media Audio Visual Video pada Mahasiswa Kelas I SMU, Lembaga Penelitian Universitas Negeri Malang

[18] Tamelan, Paul, 2015, Try Out dan Simulasi untuk meningkatkan Kemampuan Berfikir Kritis dan Kreatif Guna menunjang Ujian Nasional, Laporan
16] Sarbiran, 2006, Peningkatan Kemampuan Memecahkan Masalah dengan Pembelajaran Kontekstual dan Penggunaan Open-Ended Problems. ISSN: 0125 - 092x XXXiX, Nomor I, Tahun XVI, Mei 2006, hal. $53-68$
Psychology of Human Thought (pp.188-123), New York: Cambridge University Press

[15] Suyono, 2014, Belajar dan Pembelajaran Teori dan Konsep Dasar, Penerbit PT Remaja Rosdakarya, Bandung 